\title{
The Use of Grammar Translation Method in Teaching English
}

\author{
Catharina Elmayantie \\ STMIK Palangka Raya \\ elmayantie@ymail.com
}

\begin{abstract}
This study aims to describe the patterns of Grammar Translation Method (GTM) and to know the reasons why the teachers used the method. Descriptive qualitative method was applied. The subjects were two English teachers at the seventh grade of SMP Negeri 1 Palangka Raya. It was used observation and questionnaires to collect the data. The data reduction, data display, and conclusion drawing were applied for data analysis. The findings show nine major patterns of GTM applied: (1) The classes were taught mainly in mother tongue; (2) the vocabulary was taught in the form of lists of isolated words; (3) the grammar provided the rules for putting words together; (4) it focused on the form and inflection of words; (5) the reading difficult classical texts were begun early; (6) it was little attention to the content of the texts; (7) the drills were exercises in translating; (8) it was little attention to pronunciation; and (9) it focused on accuracy. Meanwhile, the reasons of the teachers used the method are: (1) It is suitable for the students; (2) it helps the students comprehend the text; (3) it improves the vocabulary; and (4) by using this method teaching-learning activities work well.
\end{abstract}

Keywords: English subject, grammar translation method, teaching-learning activities

Nowadays, English plays an important role in the field of the education. For examples, many kinds of textbook, journals, and other materials of knowledge and science have been published into this language and communicated mainly through printed documents. As stated by Dardjowidjojo in Halim (1999:1), English is used in nearly $85 \%$ of reference books in science. English has influenced many aspects of life. Global era makes English becomes very significant in the terms of communication among countries in the world. Therefore, in Indonesia, to prepare its people facing such impacts, English subject is taught from the elementary school level (as a local content) up to the university level.

In order to teach English effectively, the role of teaching method is badly needed. According to Brown (2001), there are various methods which can be applied in the teaching learning process. First, it is Direct Method (DM). The basic premise of $\mathrm{DM}$ is that the second language learning should be more like first language learning-lots of oral interaction, spontaneous use of the language, no translation between first and second languages, and little or no analysis of grammatical rules. 
The second one is Total Physical Response (TPR). Having fun makes language learners interested in learning the foreign language is one of the principles of this method. Total Physical Response fun is provided through physical activities. Physical activities are meant to reduce stress people feel when studying foreign languages. Since physical activities are done at the very beginning of language class, language teacher should be very selective in choosing words to teach. The language to teach should start from the words comprising verbs of imperatives and concrete nouns so that it is easier for language learners to perform and observe the actions.

The third, it is Whole Language Approach (WLA). WLA is a method of teaching reading and writing that emphasizes learning whole words and phrase by encountering them in meaningful context. The focus is on the social construction of meaning and understanding through the process of reading and writing. Students' first acquire literacy through their own writings and literature as well as experiences across the curriculum through science experiments, recipes, games, instructions for making things, math problem solving, interactive computer communications, and map reading.

The next one is Communicative Language Teaching (CLT). CLT is based on the theory of linguistic which states that language is a means of communication. The main characteristics of Communicative Language Teaching is signed by existences of information gap, choice, feedback, and authentic material.

The last, it is Grammar Translation Method (GTM). GTM is a foreign language teaching method derived from the classical (sometimes called traditional) method of teaching Greek and Latin. The method requires students to translate whole texts word for word and memorize numerous grammatical rules and exceptions as well as enormous vocabulary lists. A fundamental purpose of teaching the target language through Grammar Translation Method is to be able to read literature written in the target language.

In addition, Prator \& Murcia in Setiyadi (n.d.:17) list the major characteristics of Grammar Translation Method, as follows: (1) Classes are taught in the mother tongue, with little active use of the target language, (2) much vocabulary is taught in the form of lists of isolated words, (3) long elaborate explanations of the intricacies of grammar are given, (4) grammar provides the rules for putting words together, and instruction often focuses on the form and inflection of words, (5) reading of difficult classical texts is begun early, (6) little attention is paid to the content of texts, which are treated as exercises in grammatical analysis, (7) often the only drills are exercises in translating disconnected sentences from the target language into the mother tongue, (8) little or no attention is given to pronunciation, and (9) the focus is on accuracy, and not fluency.

Even though many new methods have been introduced to this day, Grammar Translation Method remains a standard methodology for teaching English for some teachers (Setiyadi, n.d.:17). It is in line with Harmer's statement (2007: 48-49) that Grammar Translation still has relevance. Though it is not practiced as a 
method in the same way, but most language learners translate in their heads at various stages anyway and can learn a lot about a foreign language by comparing parts of it with parts of their mother tongue. However, a total concentration on grammar translation stops students from getting the kind of natural language input that will help the students acquire language (since the students always look at L1 equivalents) and it fails to give the students opportunities to activate the language knowledge. If the teachers and the students always translate the language, the L2 is not used for communication. The danger with Grammar Translation, in other words, it teaches the students about language but does not really help the students to communicative effectively with it.

Based on the previous observation at SMP Negeri 1 Palangka Raya, the writer found that the English teachers still used the old method namely Grammar Translation Method in teaching. It is contrast with the government curriculum which advices the schools in Indonesia apply a communicative teaching learning.

In fact, SMP Negeri 1 Palangka Raya is one of the schools in preparation to be national standardized schools (Rintisan Sekolah Berstandar Nasional) in Central Kalimantan and this school has acquired " $\mathrm{A}$ " accreditation from the government. Many good achievements have been attained by the students, both local and national competitions. The recent and famous curriculum, school-based curriculum, is also implemented at the school. Based on the syllabus, the English teachers put Communicative Language Teaching (CLT) as teaching learning method. It is not the same as the implementation in the classrooms where the teachers still choose the old method or Grammar Translation Method in teaching and learning English.

Based on the background of the study, the research problems are, (1) "What are the patterns of Grammar Translation Method used by the teachers in teaching and learning English at SMP Negeri 1 Palangka Raya?" and (2) "Why do the English teachers use Grammar Translation Method in teaching and learning English at SMP Negeri 1 Palangka Raya?"

\section{METHOD}

The design of the study was descriptive qualitative method. As Bogdan (1998) defines the qualitative approach as a research procedure which produces a descriptive data such as verbal or nonverbal utterances or words from the object being observed. The subjects of the study were two English teachers at the seventh grade of SMP Negeri 1 Palangka Raya, in academic year 2011/2012. The instruments used were in the form of observation sheet and questionnaires (Sugiyono, 2007). Meanwhile, the data analysis applied in this study used data reduction, data display, and conclusion drawing/verification (Miles \& Huberman, 1994:24).

\section{FINDINGS AND DISCUSSION}

The data obtained from observation are discussed here based on the topic of the study which focused on the patterns of Grammar Translation Method in teaching English used by the teachers at the seventh grade. There were two teachers who taught at the seventh-grade students, namely teacher A and teacher B including their students observed in this study. The 
observations were done three times for each teacher. The data gotten from observation on the two teachers were described below.

\section{The Patterns of Grammar Translation}

Method in Teaching English Used by the Teachers at SMP Negeri 1 Palangka Raya

The patterns of Grammar Translation Method in teaching English used by the teachers at SMP Negeri 1 Palangka Raya are shown in Table 1.

To support the observation findings, the writer also gave the questionnaire to both teachers and their students. It was done to find out whether there was any correlation between their teaching experiences with the method they used in classroom activities, and to find out the reasons why both teachers still used Grammar Translation Method in teaching English.

\section{Questionnaire for the Teachers}

Based on the data taken from the questionnaire, both teacher $\mathrm{A}$ and teacher B had similar experience in teaching. Teacher A has been teaching English for seven years and teacher $B$ has been teaching this subject for five years. What they both found and met in the classrooms were almost the same. For the examples, they found their students had very different proficiency in English because of the different background of knowledge and they both taught in a big class which consists of thirty-five to thirty-six students.

It seemed harder to handle such a class with various attitudes towards the subject. Both of them chose the same method in teaching. Sometimes, teacher A used another method called understanding by context; meanwhile teacher B only used Grammar Translation Method in daily lesson. The data taken from questionnaire indicated that the characteristics of Grammar Translation Method had been on both teachers.

\section{Questionnaire for the Students}

There were thirty-three students asked as the respondents taken from teacher A's classroom and these students were asked to answer fifteen questions related to teaching learning process in the teacher A's classrooms. Meanwhile, there were thirty students taken as respondents from teacher B's classes with the same questionnaire. All the students' answers indicated that this method was still used in daily teaching and learning English. It supported the observation findings in the previous explanation.

\section{The Reasons of English Teachers Used Grammar Translation Method in Teaching English at SMP Negeri 1 Palangka Raya}

Basically, both teacher A and teacher B used Grammar Translation Method because this method was considered suitable for the students at this school especially the seventh grade students. By using this method, teaching English subject was much easier since many of the students still have low level of English. Most of the students cannot understand about the lesson well when the teachers try to speak in target language. 
Table 1. The Patterns of Grammar Translation Method in Teaching English

\begin{tabular}{|c|c|c|}
\hline Subject & $\begin{array}{l}\text { Characteristics of Grammar } \\
\text { Translation Method }\end{array}$ & Patterns \\
\hline \multirow{11}{*}{ Teacher A } & $\begin{array}{l}\text { Class is taught in mother } \\
\text { tongue }\end{array}$ & $\begin{array}{l}\text { Bahasa Indonesia used as the medium of } \\
\text { instruction }\end{array}$ \\
\hline & $\begin{array}{l}\text { Vocabulary is taught in the form } \\
\text { of lists of isolated words }\end{array}$ & $\begin{array}{l}\text { working with the vocabulary of the } \\
\text { passage/text }\end{array}$ \\
\hline & $\begin{array}{l}\text { Long elaborate explanations of } \\
\text { grammar are given }\end{array}$ & $\begin{array}{l}\text { Teaching grammar in detail and students } \\
\text { were required to memorize grammatical } \\
\text { rules. }\end{array}$ \\
\hline & $\begin{array}{l}\text { Grammar provides the rules for } \\
\text { putting words together, focuses } \\
\text { on the form and inflection of } \\
\text { words }\end{array}$ & $\begin{array}{l}\text { In order to show that students understand } \\
\text { the meaning and use of a new vocabulary } \\
\text { item, they made up sentences in which } \\
\text { they use the new words. }\end{array}$ \\
\hline & $\begin{array}{l}\text { Reading of difficult classical } \\
\text { texts is begun early }\end{array}$ & $\begin{array}{l}\text { Reading a long text at the beginning of the } \\
\text { meeting. }\end{array}$ \\
\hline & $\begin{array}{l}\text { Little attention is paid to the } \\
\text { content of the texts }\end{array}$ & $\begin{array}{l}\text { Doing translation in order to make } \\
\text { students know about the text and it was } \\
\text { not really important unless its vocabulary } \\
\text { such as noun, verb, adjective, or adverb. }\end{array}$ \\
\hline & $\begin{array}{l}\text { Often the drills are exercises in } \\
\text { translating disconnected } \\
\text { sentences from the target } \\
\text { language into the mother tongue }\end{array}$ & $\begin{array}{l}\text { Students translated some text sentences } \\
\text { from the target language into their native } \\
\text { language or vice versa. }\end{array}$ \\
\hline & $\begin{array}{l}\text { Little or attention is given to } \\
\text { pronunciation }\end{array}$ & $\begin{array}{l}\text { The focused of the lesson was translating } \\
\text { words or sentences. }\end{array}$ \\
\hline & $\begin{array}{l}\text { The focus is on accuracy, and } \\
\text { not fluency }\end{array}$ & $\begin{array}{l}\text { Teaching the students about the } \\
\text { grammatical rules and vocabulary of the } \\
\text { target language and giving the exercises in } \\
\text { grammatical analysis. }\end{array}$ \\
\hline & Class is taught in mother tongue & $\begin{array}{l}\text { Explaining the material in Bahasa } \\
\text { Indonesia. }\end{array}$ \\
\hline & $\begin{array}{l}\text { Vocabulary is taught in the form } \\
\text { of lists of isolated words }\end{array}$ & $\begin{array}{l}\text { Asking the students to find out some } \\
\text { difficult words in the reading text and } \\
\text { doing translation. }\end{array}$ \\
\hline
\end{tabular}

Teacher B grammar are given up three meetings.

; Grammar provides the rules for putting words together, focuses on the form and inflection of Giving tasks in arranging words form. words

$\begin{array}{ll}\text { Reading of difficult classical } & \begin{array}{l}\text { Together reading a text or asking the } \\ \text { students by one to read it at the beginning }\end{array}\end{array}$


of the meeting.

$\begin{array}{ll}\begin{array}{l}\text { Little attention is paid to the } \\ \text { content of the texts }\end{array} & \begin{array}{l}\text { The forms of the sentences in the text were } \\ \text { focused in teaching reading. }\end{array} \\ \begin{array}{l}\text { Often the drills are exercises in } \\ \text { translating disconnected } \\ \text { sentences from the target } \\ \text { language into the mother tongue }\end{array} & \begin{array}{l}\text { Students translated some text sentences } \\ \text { from the target language into their native } \\ \text { language or vice versa. }\end{array} \\ \begin{array}{ll}\text { Little or attention is given to } \\ \text { pronunciation }\end{array} & \begin{array}{l}\text { Pronouncing vocabulary given, students } \\ \text { only listened to the teacher. }\end{array} \\ \begin{array}{l}\text { The focus is on accuracy, and } \\ \text { not fluency }\end{array} & \begin{array}{l}\text { Teaching the students about the } \\ \text { grammatical rules and vocabulary of the } \\ \text { target language and giving the exercises in } \\ \text { grammatical analysis. }\end{array} \\ \end{array}$

Besides, by using this method, it can help the students to comprehend the text given and know the grammatical rules of a language. This method also can improve the students' vocabulary better. It is very important for the student to master the sentence pattern and vocabulary as this knowledge is badly needed to pass the examination which often in form of grammar oriented and reading comprehension. Mastering the grammar of the foreign language is essential in order for the students to understand the written target language.

Moreover, this subject is one of the subjects tested on the national examination. It is the teachers' responsibility to give good foundation in the target language as the preparation for next grade. Therefore, in teaching English, both teachers for the seventh grade used Grammar Translation Method with little combination of communicative approach. Both of them thought this method was still relevant to teach English as a foreign language. Teaching learning activity worked well and the result could be seen on the students' achievement through the assignments given during the end of the semester.

\section{CONCLUSION}

Based on the observations and data gained from questionnaire supported by written records such as curriculum/syllabus, lesson plan, handbook used by the teachers and the students in teaching learning English, the writer found the nine patterns of Grammar Translation Method used by the two teachers of the seventh grade students at SMP Negeri 1 Palangka Raya, such as: (1) the classes were taught mainly in mother tongue (Bahasa Indonesia); (2) the vocabulary was taught in the form of lists of isolated words; long elaborated explanations of grammar; (3) the grammar provided the rules for putting words together; (4) it focused on the form and inflection of words; (5) reading difficult classical texts were begun early; (6) it was little attention to the content of the texts; (7) often the drills were exercises in translating disconnected sentences from the target language into the mother tongue; (8) little attention was given to pronunciation; and (9) the focus was on 
accuracy, not fluency. The reasons of the teachers for the seventh grade students used Grammar Translation Method in teaching learning English are: (1) this method is considered suitable for the students at this school especially the seven grade students who have low level of English; (2) by using this method, it helps the students to comprehend the text given, especially in teaching reading and know the grammatical rules of a language; (3) Grammar Translation Method also can improve the students' vocabulary better; and (4) by using Grammar Translation Method with little combination of communicative approach, teaching learning activity work well.

To follow up the conclusion, some suggestions are proposed to the English teachers and future researchers. For the English teachers of SMP Negeri 1 Palangka Raya, it is recommended to apply more various methods in teaching and learning, and it is not only focused on use of the methods for teaching the components of language but also for teaching the four language skills. Then, for the future researchers are recommended to conduct such kind of the study concerned with Grammar Translation Method in a wider scope and setting.

\section{REFERENCES}

Bogdan, R. (1998). Qualitative research for education: An introduction to theory and methods ( $3^{\text {rd }}$ ed.). New York: A Viacom Company.

Brown, H. D. (2001). Teaching by principles: An interactive approach to language pedagogy (2 ${ }^{\text {nd }}$ ed.). New York: Addison Wesley Longman, Inc.

Halim, T. (1999). Developing reading comprehension materials for graduate students of the state university of Malang. Unpublished Thesis. Malang: State University of Malang.

Harmer, J. (2007). How to teach English. London: Pearson Education Limited.

Miles, M. B \& Huberman, M. (1994). Qualitative data analysis: An expanded sourcebook. Beverly Hills: SAGE Publication Inc.

Setiyadi, B. (n.d.) TEFL II: Modul edisi kedua. Pusat Penerbitan Universitas Terbuka.

Sugiyono. (2007). Metode penelitian: Pendekatan kuantitaif, kualitatif, $R \mathcal{E} D$. Bandung: Alfabeta. 
132 | Journal on English as a Foreign Language, Volume 5, Number 2, September 2015 